4. Comparative study of the interaction of polyuridylic acid with $30 \mathrm{~S}$ subunits and $70 \mathrm{~S}$ ribosomes of Escherichia coli/ V. I. Katunin, Yu. P. Semenkov, V. I. Makno, S. V. Kirillov.- Ibid., N 2, p. 403-421.

5. Sprinzl M., Sternbach H. Enzymatic modification of the C-C-A terminus.- Meth. Enzymol., 1979, 59, p. 182-190.

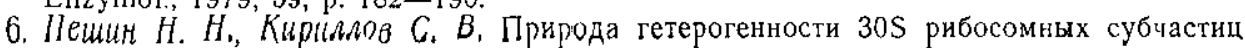
in vitro. II. Два типа ннактивации $30 \mathrm{~S}$ субчастиц рибосом Escherichia coli. - Молекуляр. биология, 1979,13 , № 4 , с. $752-759$.

7. Kirillov S. V., Makarov E. M., Semenkoy Yu. P. Quantitative study of interaction of deacylation tRNA with Escherichia coli ribosomes. - FEBS Lett., 1983, 157, N 1, p. $91-94$

8. Rheinberger $H$. J., Sternbach $H_{.}$, Nierhaus $K$. $H$. Three tRNA binding sites on Escherichia coli ribosomes. - Proc. Nat. Acad. Sci. USA, 1981, 78, N 9, p. 5310-5314.

9. Grajevskaja $R$. A., Ivanov $Y_{u}$. V., Saminsky E. M. 70 S ribosomes of Escherichia coli have an additional site for deacylated tRNA binding.-Eur. J. Biochem., 1982, 128, N 1, p. $47-52$

10. Кириллов C. B. Механизмы кодон-антикодонового взаимодействия в рибосомах.В кн.: Итоги науки и техники. М.: ВИНИТИ, 1983, с. 5-97.- (Сер. Биологическая химия; т. 18)

11. Кириллов С. В., Семенков Ю. П. Взаимодействие тРНК с рибосомами.- Молекуляр. бнология, 1984, 18, № 5, с. 1249-1263.

12. Mechanism of codon-anticodon interaction in ribosomes/S. V. Kirillov, K. Sh. Kemkhadze, E. M. Makarov et al.--FEBS Lett., 1980, 120, N 2, p. 22l-224.

13. Odom $O$. W. Stoffler G., Hardesty B. Movement of the $3^{\prime}$-end of $16 \mathrm{~S}$ RNA towards S21 during activation of $30 \mathrm{~S}$ ribosomal subunits.- Ibid., 1984, 173, N 1, p. 155-158.

14. Chiaruttini $C$., Milet $M$., Hayes $D$. Structural differences between active and inactive $30 \mathrm{~S}$ ribosomal subunits revealed by RNA - protein crosslinking.-Ibid., p. 90-94.

15. Ohsawa H., Gualerzi C. Chemical modification in silu of Escherichia coli $30 \mathrm{~S}$ ribosomal proteins by the site-specific reagent pyridoxal phosphatc. Inactivation of the aminoacyl-tRNA and mRNA binding sites.-J. Biol. Chem., 1983, 258, N 1, p. $150-$ 156 .

16. Uhlenbeck O. C., Lowary P. T., Wittenberg W. L. Role of the constant uridine in binding of yeast tRNA phe anticodon arm to $30 \mathrm{~S}$ ribosome. - Nucl. Acids Res., 1982, 10, N 11, p. 334l-3352.

17. Binding of complementary oligonucleotides to aminoacylated tRNA ${ }^{\text {Phe }}$ from yeast./ O. Pongs et al.-Biochem. and Biophys. Res. Communs, 1976, 71, N 4, p. 10251033.

18. Crothers D. M. Cole P. E. Conformational changes of tRNA.-In: Transfer RNA/ Ed. S. Altman. London : MIT press, 1978, p. 197-247.

19. Gassen $1 / . G$. Ligand-induced conformational changes in ribonucleic acids.-Progr. Nucl. Acid Res. and Mol. Biol., 1980, 24, p. 57-86.

20. Nagamatsu K., Miyazawa Y. Magnesium cation induced conformational change of yeast tRNA ${ }^{\text {Phe }}$ as studied by singlet-singlet energy transfer.-J. Biochem., 1983, 94, N 6, p. $1967-1971$.

Отдел генетики растений AY MCCP, Киншнев

Јенинград. ин-т ядерной физики

Получено 09.04.85

им. Б. ПП. Константніова АН СССР, Гатчина

УДК 547.963 .3

ИЗУЧЕНИЕ

МОЛЕКУЛЯРНЫХ МЕХАНИЗМОВ ГИПОАЛЬБУМИНЕМИИ НА МОДЕЛИ ЭКСПЕРИМЕНТАЛЬНОГО ИНФАРКТА МИОКАРДА

\author{
А. В. Лекис, Л. Ю. Лукошявичюс, М. И. Коваленко, О. В. Булдакова
}

Снижение количества альбумина в сыворотке крови при различных патологических состояниях, в том числе при инфаркте миокарда, показано как в клинических исследованиях, так и на различных экспериментальных моделях. Вместе с тем, молекулярнце мехаиизмы развития гипоальбуминемии практически не изучены. Согласно данным, полученным пами ранее [1], в первые сутки экспериментального инфаркта миокарда (ЭИМ) уменьшается доля мембраносвязанных рибосом в суммарном пуле рибосом печени. Как известно, с этим классом рибосом связан синтез сывороточного альбумина в клетках печени [2]. В настоящей работе изучен уровень синтеза альбумина и суммарных белков печени in vivo и in vitro и определено время синтеза «средней» полипептидной цепи в печени после ЭИМ. 
Материалы и методы. Исслсдования проведены на кроликах-самцах массой 2,5 3,0 кг. Моделью экспериментальнго инфаркта миокарла служнла окклюзия левой иисходяцей ветви коронарной артерии. Торакотомик производили под тиопешталовым наркозом (40 мг/кг), степень ишемии контролировали электрокардиографически [3]. Материалом для исслсдования служила печень жнвотыых через 6,12 и 24 ч после окклюзии коронаріой артерии и в те же сроки после торакотомии. В качсстве коптроля использовали печень интактых животных. Содержание белка определяли по методу Лоури [4]. Количество альбумина в сыворотке крови рассинтывали после ее фракциоиировани методом диск-з.Ісктрофореза в ПААГ [5]. Для опрсдслсния времени снштеза «средлсӥ» нолипептидый щепи в печели, а также уровня синтеза суммарных белков и альбумнна животным вводили внутрибрюшинно смесь ${ }^{14} \mathrm{C}$-аминокислот (240$360 \mathrm{MKн/ммоль)} \mathrm{из} \mathrm{расчета} \mathrm{1,6} \mathrm{мКи} \mathrm{на} 1 \mathrm{kr}$ массы. Время синтеза «средней» полипептнднӧ̈ цепи опреденяли согласло методу [6]. О6 уровлс бслконого сннтеза судили по включению радноактивой метки в 'ТХУ-нерастворимый осадок гомогсната ткани через 15 мин после ее введения жнвотным. Эндогенные аминоацил-тРНК были предварительно разрушены пикубащией гомогената ткани в 0,1 н. КОН при $37^{\circ} \mathrm{C}$. Уровень синтеза альбумина в печени определяли по включенню мсченых аминокислот в фракцию белков, осаждаемых антисывороткой к альбумину. Алтисыворотку получали иммунизацией крыс высокоочищенным альбумином кролика [7]. Титр антител проверяли по реакции Оухтерлони [8]. Эквивалентную точку преципитации устанавлинали, как пписало [9]. Иммунопреципитацию альбумина пронодили слспуюцим образом: в про$6 y$, содержашую 300 мкл гомогената ткани, добавляли 10 мкл є̇льбумина $(0,25$ мг/мл) ॥ 100 мкл антисыворотки с титром $1: 4$. Смесл илкубировали 1 п при $37^{\circ} \mathrm{C}$ и оставляли га ночь при $4{ }^{\circ} \mathrm{C}$. Иммунопреципитаты собирали на нитронелююлозных фнльтрах Сынпор (ЧССР) и тщательно отмывати 20 мM калй-фосфатным буфером, $\mathrm{pH} 7,5$, содержашим $0,14 \mathrm{M} \mathrm{NaCl}, 0.5 \%$ тритола X-100. В контролышые пробы добавляни сыворотку иеиммулизированных животных.

Цля получешия бесклеточной белоксиштезируюшей системы печеш гомогенизировали в 2,5 обьемах 30 мM HEPES-буфера ( $\mathrm{H}$ 7,5), содержащего $0,25 \mathrm{M}$ сахарозу, $70 \mathrm{mM} \mathrm{ҚC1,} 5$ мМ ацетат магния, 0,25 мМ ЭДТА, 2 мМ дитиотреитол. Гомогенат центрифугировали 15 мин при $30000 \mathrm{~g}$ и супернатант обозначали как «неочицениая $\mathrm{S}-30$ фракция». Часть этой фракции фильтровали через гель сефадекса G-25 лля оснобожления от низкомолскулярных соединенй и обозначали как «очишелная $\mathrm{S}-30$ фракция». Стандартная инкубациогная смесь в объеме 100 мкл содержала 30 мM HEPES-буфер $(\mathrm{pH} 7,5), 0,5$ мM ATP, 0,02 мM GTP, 10 мM креатин-фосфат (ҚФ), 2 мкг креатинфосфокиназы (КФК), 0,02 мМ раствор 19 немечсных аминокислот (исклютая лейцин), $0,02 \mathrm{mM}{ }^{14} \mathrm{C}$-лейцил $(240 \mathrm{mKи/ммоль),} 5$ мМ ашетат магния, $120 \mathrm{mM} \mathrm{KCl,} 2$ мМ дитиотреитол и 1 опт. ел. $\mathrm{A}_{260}-\mathrm{A}_{320}$ очишениой $\mathrm{S}-30$ фракции. В случае неочишениой $\mathrm{S}-30$ фракиии щлубациопная смесь солержала те же компонелты, кроме АTP, GTP, КФ, ҚФҚ и неисченых аминокислот. Установлено, цто для максимального образовання продукта трансляции необходимое время инкубация 30 мил при $37^{\circ} \mathrm{C}$. Реакцию осташавливали добавлением 0,5 мл 0,1 н. КОН, затем по истечспни 20 мин илкубацин при $37^{\circ} \mathrm{C}$ к пробам добавляли 0,5 мл $10 \%$-ной ТХУ и выдерживали на ледяной бане 1 ч. Осадки налосили на нитроцеллюлозные фильтры и промынали $5 \%$-лой ТХУ. Јровень синтеза альбумниа в беск.тетоной белоксинтезируюшей системе определяли с помошью иммунопреципитации [10]. Для этого из сыворотки крови крыс, иммугизированных альбумнном кролика, осаждали сульфатом аммолня фракцию ү-глобулигов [11]. Иммулопрсципитаты собиралн на пнтроцсллюлозные фильтры, отмывали 50 мМ трис-HC1 буфером (pI 7,5), содержащим $5 \mathrm{mM} \mathrm{MgCl}_{2}, 100 \mathrm{MM} \mathrm{KC1}, 0,5 \%$ тритона X-100 и огределяли радноактивность в толуоловом сцилтиллиторе в счетчике Delta-300. B контрольлые пробы добавляли ү-глобулины, выделепные из сыворотки пенммупизированных животных.

Результаты и обсуждение. Согласно данным, представлснным в табл. 1, в первые сугки ЭИМ, начиная с 6 ч, в сыворотке крови наблюдается снижение содержания как обшего белка, так и альбумина. Одной из причин гипоальбуминемии при ЭИМ может быть снижение уровня синтеза в печени. В связи с этим предположением был определен уровень синтеза суммариых белков и альбумила в печели in vivo. Оказалось, что уже в первые часы после окклюзи коронарной артерии включепие мечешых амишокислот в ТХУ-нсрастворимую фракцию гомогената печени и во фракцию белков, осажлаемых антиальбуминовой сывороткой, снижено (табл. 2). Процссс трансляцин может быть охарактеризован с помощью определения времени синтеза «средней» полипептнднй цепи, Изучение этого параметра показало его существенное увеличение при ЭИМ. Если в печени контрольных животных время синтеза «срепней» полипептидной цепи состав.!яет 3,4 мин, то уже в иервые часы ЭИМ оно возрастаст, достигая паибольщей встичины через 12 ч $-6,3$ мнн

При сопоставлспии даиных, представленных в таблицах 1 и 2, видно, что умень шению содержания альбмнша в сыворотке крови при ЭИМ предшествует сушественпое слижение включелия меченых амилокнслот как в суммарные белки печени, так и в альбумиловую фракцию. Значительное возрастание времені синтеза «средней» поли. пептидлой цепи также сьидстельствует в определенгой мере о снижснии обшей ско- 
рости белкового синтеза в печени. Для выяснения причин обнаруженного явления дальнейшие исследования были паправлепы на изучение скорости и эффективности трансляции эндогеных мРНК в беск'еточных белоксиптезирующих системах из печени с использованием очищенной и нсочищенной S-30 фракций. Бесклеточная белоксиптезирующая система, содержашая пеонщениую S-30 фракцию, в больией мере отражает уровень сиятеза белка в цитоплазме in oiю, так как в пей используются соб. ственные ресурсы для синтеза белка. Согылсн данным табл. 3, включение мстки в продукт трансляции ниже в присутствин S-30 фракции, полуленной из печени животных иерез 6-12 т ЭИМ по сравненню с контролем. Возникает вопрос-связано ли сниженис актниноси белокситезирующей бескиеточной системы из печени опытых животных с уменьшением энергетического обеспечения пропесса трапсляци ин со снижением белоксинезируюцей способиости самого аппарата трансляни. Для его решения бына использована очищениая от низкомолекулярных соединеий S-30 фракция и подобраны оптимальные концентрации АТP, GTP, ҚФ и ҚФҚ в инкубациопой смеси. Оказалось, что в таком варианте уровень синтеза белка в системе, выделенной из печени животиых, уже через 6 ч посте воспронзведепия ЭИМ не только постигает контрольного уровня, но и превышает его (табл. 3 ).

Т а 6 ли ц а 1

Содержание обиего белка и алибулина в сыворотке крови кроликов при .ЭИМ ( $\mathrm{ma} / \mathrm{M}, M \pm m, n=10-15)$

Total protein and albumin content in rabbit serum during EIM

( $m g / m l, M \pm m, n=10-15)$

\begin{tabular}{|c|c|c|c|c|c|c|c|c|c|}
\hline \multirow{2}{*}{ Контроль } & \multicolumn{9}{|c|}{ Время ЭИМ, ч. } \\
\hline & & 6 & & 12 & 24 & & 48 & & 72 \\
\hline \multicolumn{10}{|c|}{ Общий белок } \\
\hline $74,2 \pm 3,2$ & 1 & $67,4 \pm 2,3^{*}$ & 1 & $66,5 \pm 2,5$ & | $58,9 \pm 3,2$ & I & $58,2 \pm 2,0$ & 1 & $69,6 \pm 3,3^{*}$ \\
\hline \multicolumn{10}{|c|}{ Альбумин } \\
\hline $37,1 \pm 2,6$ & 1 & $31,1 \pm 3,3^{*}$ & 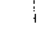 & $26,0 \pm 1,9$ & $23,6 \pm 2,5$ & 1 & $23.3 \pm 2,6$ & I & $27,2 \pm 3,1^{*}$ \\
\hline
\end{tabular}

П р и м е ани е. В таблицах $1-5$ не привелены данныс, полученныс на торакотомированных животных, так как они илентичны ланным контролыных животных. *-Раз.личия недостоверны.

Т а б ли ц а 2

Вклочение ${ }^{14}$ C-аминокислот в суммарные белки печени и альбумин (usn/utн/10 ne белка, $M \pm m, n=3-5$ )

"C-amino acids incorporation into total proteins and albumin from rabbit liver (cpm/10 mg protein, $M \pm m, n=3-5$ )

\begin{tabular}{|c|c|c|c|c|c|c|}
\hline \multirow[b]{2}{*}{ Контроль } & \multicolumn{6}{|c|}{ Время ЭИМ, ч } \\
\hline & & 6 & & 12 & & 24 \\
\hline \multicolumn{7}{|c|}{ Суммарные белки } \\
\hline $3023 \pm 299$ & $!$ & $1640 \pm 310$ & 1 & $1007 \pm 310$ & I & $2357 \pm 396^{*}$ \\
\hline \multicolumn{7}{|c|}{ Альбумин } \\
\hline $904 \pm 29$ & 1 & $425 \pm 35$ & ! & $335 \pm 34$ & I & $580 \pm 38$ \\
\hline
\end{tabular}

Известно, что в первые сутки инфаркта мнокарда нарушается энергетический обмен не только в сердечной мышще, но и в печени $[12,13]$. В связи с этим можно предположить, что энергетнческое обеспечение неочиненой белоксинтезируюпей систсмы из пелени при ЭИМ недостаточно для оптимального функционирования белоксинтезируюпего аппарата. В плане проверки этого предположения было изугено включение "С-лейцина в тотальный продукт трансляции при внесении в такую систему бесклеточного синтеза белка различных количеств АТP, GTP и КФ. Увеличение в си- 
стеме концсптриции АЧР прнводит $\mathrm{k}$ повыпению синтеза белка, однако до опреде ленной величины, которая пе достигает контрольлого уровня. Внесение в инкубационную смесь GTP практически не влияет на уровень вкуючения меченой аминокислоты в продукт трансляции (данные не приведены). В то же время, при увсличелии в ин. кубапионий смеси КФ ;о 60 мМ уровень синтеза белка возрастает в неониенной системе, вылеленной из печсни кроликов в разииныс сроки ЭИМ, превцшает конт. рогызый уровен, (таб́г. 3).

Т а 6.1 н ц а 3

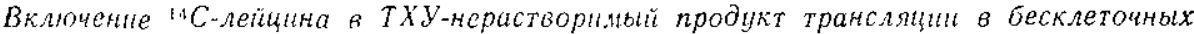
белоксинтезириоцих спстенах из печени (nuonill o. e. $S-30, M \pm m, n=1--18$ )

${ }^{14}$ C-letcine incorporation TCA-insoluble product of translation in rabbit liver coll free systems (pmoles/1 o. $u . S-30, M \pm m, n=1.1-18$ )

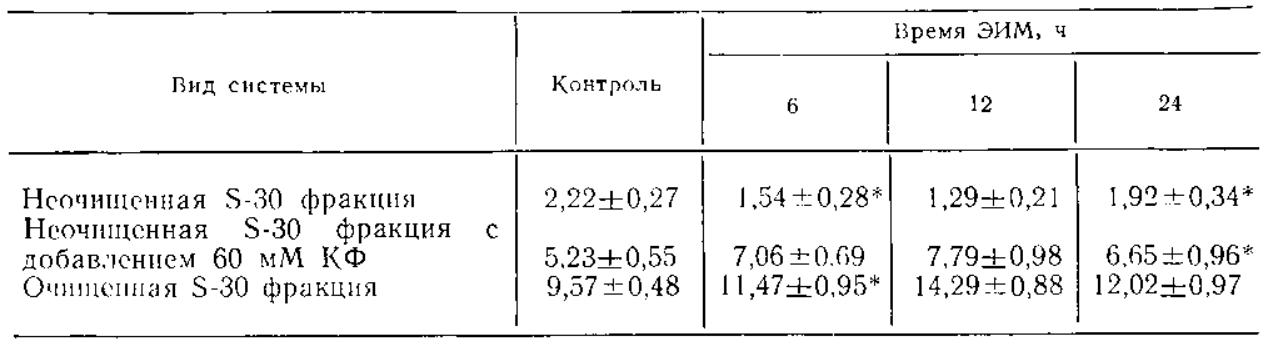

Т а б ли ц а 4

Включение ${ }^{14}$ С-лейчина в альбинин, синтезированный в бесклеточной белоксинтезириюuей cuctenе

${ }^{14} \mathrm{C}$-leucine incorporation into the albumin synthesized in rabbit liver cell free systems (pmoles/1 o. $u . S-30, M \pm m, n=8-10$ )

\begin{tabular}{|c|c|c|c|c|}
\hline \multirow[b]{2}{*}{ Внд системы } & \multirow[b]{2}{*}{ Контроль } & \multicolumn{3}{|c|}{ Iзремsт ЭНМ, ч } \\
\hline & & 6 & 12 & 24 \\
\hline $\begin{array}{l}\text { Очишеншая S-30 фракция } \\
\text { Нсочипенная S-30 фракция с до- } \\
\text { бав.]снием } 60 \text { мM КФ }\end{array}$ & $\begin{array}{l}3,24 \pm 0,16 \\
2,38 \pm 0,15\end{array}$ & $\begin{array}{l}2,88 \pm 0,24^{*} \\
2,07 \pm 0,22^{*}\end{array}$ & $\begin{array}{l}2,63 \pm 0,18 \\
1,78 \pm 0,19\end{array}$ & $\begin{array}{l}2,94 \pm 0,26^{*} \\
2,01 \pm 0,29^{*}\end{array}$ \\
\hline
\end{tabular}

Т а бли ц а 5

Соотношение профиктов трансляции, осаждаемых иммунопреципитацией и ТХУ $(M \pm m, n=8-10)$

Ratio of translation products precipitated with antialbumine serum and trichloracetic acid $(M \pm m, n=8-10)$

\begin{tabular}{|c|c|c|c|c|}
\hline \multirow[b]{2}{*}{ Вид системы } & \multirow[b]{2}{*}{ Контроль } & \multicolumn{3}{|c|}{ Время ЭИМ, ч } \\
\hline & & 6 & 12 & 24 \\
\hline $\begin{array}{l}\text { Очищенная } S-30 \text { фракция } \\
\text { Неочиценная } S-30 \text { фракция с до- } \\
\text { бав.тенися } 60 \text { м } M \text { КФ }\end{array}$ & $\begin{array}{l}0,33 \pm 0,02 \\
0,45 \pm 0,05\end{array}$ & $\begin{array}{l}0,26 \pm 0,01 \\
0,29 \pm 0,07^{*}\end{array}$ & $\begin{array}{l}0,20 \pm 0,02 \\
0,23 \pm 0,08\end{array}$ & $\begin{array}{l}0,24 \pm 0,02 \\
0,29+0,08^{*}\end{array}$ \\
\hline
\end{tabular}

Прн инфаркте миокарда в результате нарушения окислительного фосфорилирования в печени уменьшается количество АТР и креатинфосфата [13]. В связи с этим внссенис АТР в неочищенную систему бесклеточного синтеза белка приводит, по-нидимому, лишь к кратковременной компенсации недостатка энергетических ресурсов в процессе синтеза белка. Добавление КФ подключает креатинфосфокиназную систему, которая поддерживает содержание АTP, а следовательн, и GTP на постояниом уровне Известно, что отношение $\mathrm{DDP} / \mathrm{ATP}$ п GDP/GTP весьма существенп для уровия и скорости бе.'ікового синтеза 
В следующей серии опытов был изучен уровень синтеза альбумина по отношению к общему уровню синтеза белков печени. Проведено сравнительное определение радиоактивности продуктов трансляции, осаждаемых ТХУ и нммунопреципитацией. Данные, прнве,деные в табл. 4 н 5 , свидетельствуют о том, что при $Э И М$ в бесклеточной белокситезирующей системс с очищенной и неочищенной S-30 фракпией снижастся как абсолютный синтез альбумина, так и доля его в тотальном продукте трансляции. Нанболее низкий уровен сиятеза альбумина паблюдается в белоксинтезирующих системах, полученых из печени чсрез 12 ч ЭИМ. Повынине концентрации КФ в инкубационной смеси приводит к увеличению синтеза только тотального продукта трансляции, но не изменяет уровня синтеза альбумина в системах, выделених из печени при ӘИМ. Различия в уровне белкового спитеза в очищснной и неочиенной $\mathrm{S}-30$ фракциях, по-видимому, связаны с паличием в последней низкомолекулярных нигпбиторов трансляции [14].

Итак, обнаружениые при ЭИМ изменения уровня синтеза суммарных белков петени и альбумина, всроятно, обусловлены различными факторами. Если снижение синтез‘ белка в печени в целом при ЭИМ можно связать с недостатком энергетических ресурсов в клетке, то уменьшение синтеза альбумина нельзя объяснить только этой причиной. Выше отмечалось, что в первые 12 ч ЭНМ в печени вместе с изменением соотношения мембраносвязанных и свободных рнбосом в пользу последних, происходит сиижение доли полисомного материала в классе мембрапосвязанных рибосом [1], на которых происходит синтез альбумина. Показано, что причиной сиижения количества мембраносвязанных рибосом в печени при ишемии может быть мменшене связывяю. щей способности мембрап [2]. Другой возможной прнчиной снижения уровня синтеза альбумина может быть уменьшение содержания соответствуюших мРНK в рсзупьтате их ускоренной деградации при ЭИМ. Есть данные, что регуляция деградации мРIK осуществляется на уровне мембраи эндоплазматического ретикулума [15]. Безусловно, для пронсрки справедливости высказаншых предположений необходимы далынйшне исследования.

\section{STUDY OF THE MOLECULAR MECHANISMS OF HYPOALBUMINEMIA UNDER EXPERIMENTAL, MYOCARDIAL INFARCTION}

A. V. Lekis, L. Yu. Lukosherichius, M. I. Kovalenko, O. V. Buldakoz'a

Institute of Molecular Biology and Genetics,

Academy of Sciences of the Ukrainian SSR, Kiev:

Medical Institute, Lithuanian SSR, Kaunas

\section{Sum m a y}

The decrease in the level of the total protein synthesis in the liver and an almost twofold increase in the «average» polypeptide chain synthesis time are shown in the case of the experimental myocardial infarction (EMI). A considerable decrease in the incorporation of radioactive amino acids into albumin is established by means of immunoprecipitation with antialbumin serum. In cell-free systems it has been shown that a decrease in the total protein biosynthesis under EMI in liver is caused by the dificiency in the energy supply of the translation process, while reduction of the albumin synthesis in the case of EMI cannot be only due to this factor.

1. Jleки А. В., Потапов А. П., Лукоильичюс Л. Ю. Изменения в пуле рибосом в ранние сроки экспериментального инфаркта миокарда.- Молекуляр. биология, 1984 , вып. 37 , с. $22-25$.

2. Лишневская E. В. Мембраносвязанные рибосомы-Успехи соврем. биологии, 1977, 83 , № 2, c. $182-197$.

3. Mitochondrial functions in ischemic myocardium/A. Toleikis, P. Dzeja, A. Prashkevicius et al.-J. Mol. and Cell Cardiol., 1979, 11, N 1, p. 55-76.

4. Protein measurement with the folin reagent/O. Lowry, $H$. Rosenbrought, A. Farr et al.-J. Biol. Chem., 1951, 201, N 1, p. 265-275.

5. Ажиикий $\Gamma$. Ю., Багдасарьян $C$. $H$. О возможности выделения мономерного имму. нохимически чистого альбумина.- Лаб. дело, 1975,12 , с. $712-714$.

6. Лейтин B. Л., Лерлан М. Н. Методы определения времени синтеза полипептидной цепи.-В кн.: Современные методы в биохимии. М.: Медицина, 1977, с. 277-285.

7. Chemical and immunochemical characterization and major whey proteins of rabbit milk/R. Dayal, J. Hurliman, J. M. Suarf et al.--Biochem. J., 1982, 201, N 1, p. 7 t-79. 
8. Ouchterlony 0 . Cell-diffusion techniques in immunochemie. 15 Colloquium Ges. Physiol. Chem. Springer. Berlin, Heidelberg, New York, 1965, p. 13-35.

9. Al-Sarra J.K., White $D$. A., Mayer R. J. Immunochemical characterization of casein from rabbit mammary gland.-- Biochem. J., 1978, 173, N 4, p. 877-883.

10. Роль функциональной адаптации тРНК в регуляции биосинтеза спсцифитеских белков / А. В. Ельская, Г. В. Турковская, О. Т. Рожко, Н. Ф. Стародуб.- Биохимия, 1983,48, № 4, с. $611-616$

11. Лефковитс Н., Пернис Б. Иммуноглобулины крыс--В кн.: Методы пісследований в иммунологии. М.: Мир, 1981 , с. 61 .

12. Гузеева B. A. О патологии печени при инфаркте миокарда.-Қардиология, 1977, 17, № 1 , c. 1T9-I 23 .

13. Прижизненное изучение энергетнтеского обмена печени у больных митральным стенозом/Е.Н. Мешалкин, Л. А. Кремлева, Г. Ф. Архипова и др.-Там же, 1977, 17, № 1 , c. $54-57$

14. Угарова Т. Ю. Эукариотические бесклеточные белоксинтезирующие системы. В кн.: Итоги науки ға техники. М.: ВИНИТИ, 1976, с. 58-141. (Сер. Молекуляр. биология; Т. 7).

15. Арбузов B. A. Регуляция синтеза белка. Стабнльность мРНК как один из факторов регуляции синтеза белка в клетках эукариотов.-Успехи современ. биол., 1977,83 , № 2 , c. $163-181$.

Каунас. мед. ин-т МЗ ЛатвССР

Получено 26.12 .84

Ин-Т молекуляр. биологии и генетики АН УССР,

Киев 